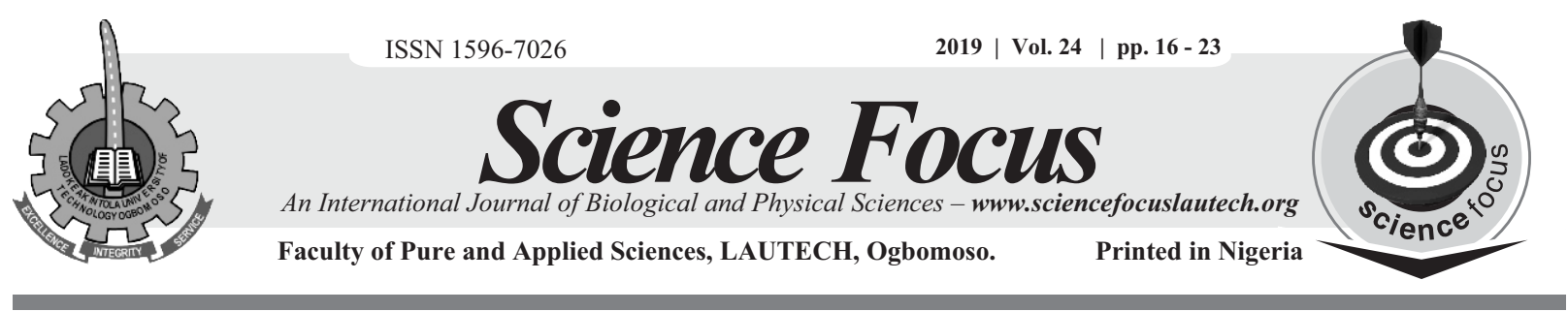

https://doi.org/10.36293/sfj.2019.0041

\title{
ASSESSMENT OF RADIONUCLIDE CONTENT IN SOME SELECTED TUBERS IN OGBOMOSO METROPOLIS OF SOUTH-WESTERN NIGERIA.
}

\author{
AKINRINOLA, $0^{1}$, ONI, O.M ${ }^{1}$, AREMU, A.A ${ }^{3}$, OLADAPO, O.O ${ }^{2}$, ONI, E.A ${ }^{4}$, \\ OJENIYI, F.A ${ }^{4}$ and AKINRINOLA O.A ${ }^{1}$.
}

\author{
${ }^{\prime}$ Department of Physics, Ladoke Akintola University of Technology, Ogbomoso. \\ ${ }^{2}$ Department of Science Laboratory Technology, Ladoke Akintola University of Technology, Ogbomoso. \\ ${ }^{3}$ Department of Physics, Dominion University, Ibadan. Oyo State \\ ${ }^{4}$ Oduduwa University, Ipetumodu. Osun State
}

\begin{abstract}
A radioactivity concentration survey was conducted in some commonly consumed tubers (Yam, Cassava and Sweet Potatoes) within Ogbomoso metropolis area of South Western Nigeria. The study area was divided into four zones (ABCD) based on soil formations of the study area and the tubers were collected from agricultural farms where they were produced. Food crop/tubers were dried at room temperatures until mass would change, powdered with the aid of pestle and mortal and then sieved with a $1.00 \mathrm{~mm}$ mesh. Gamma spectroscopy analysis of all the samples was done after they had attained secular equilibrium. Mean specific activity values obtained for ${ }^{40} \mathrm{~K},{ }^{238} \mathrm{U}$ and ${ }^{232} \mathrm{Th}$ are $1190.76 \pm 77.10 \mathrm{~Bq} / \mathrm{kg}$, $37.84 \pm 6.22 \mathrm{~Bq} / \mathrm{kg}$ and $17.52 \pm 1.15 \mathrm{~Bq} / \mathrm{kg}$ respectively for cassava (Manihot esculenta), $779.05 \pm 43.36$ $\mathrm{Bq} / \mathrm{kg}, 40.49 \pm 6.89 \mathrm{~Bq} / \mathrm{kg}$ and $10.47 \pm 0.84 \mathrm{~Bq} / \mathrm{kg}$ respectively for Yam (Discorea spp) and $1282.83 \pm$ $71.33 \mathrm{~Bq} / \mathrm{kg}, 37.80 \pm 6.51 \mathrm{~Bq} / \mathrm{kg}$ and $21.13 \pm 1.37 \mathrm{~Bq} / \mathrm{kg}$ respectively for Potato (Ipomoea batatas). With these known, absorbed dose rate, radium equivalent activity, activity concentration index, external hazard index and effective dose rate were obtained. However, with the obtained values, the tubers are not expected to be harmful as consumed.
\end{abstract}

Keywords:

Corresponding Author Email: adewest2002@gmail.com 


\section{Introduction}

The earth contained varied levels of radioactivity due to chain decay of natural radio nuclides ${ }^{238} \mathrm{U},{ }^{228} \mathrm{Th}$ and ${ }^{40} \mathrm{~K}$ (Saleh, 2011,). The effect of soil features, geological formations and human activities (farming, bush burning and mining) have correlation with the background levels of natural radiation (Jwanbot et al., 2012). Significant contribution is done by the naturally occurring radionuclides of ${ }^{238} \mathrm{Th}$ and ${ }^{238} \mathrm{U}$ to ingestion dose and are present in the biotic system of plant, animal, soil, water and air (Jwanbot et al., 2012). The exposures of Humans to naturally occurring radioactive materials (NORM) are through the environmental media such as; air, intake food, soil, water (through drinking, washing and bathing) and even within the bodies (Ademola, 2008, Avwiri et al., 2013). The presence of radionuclides in food is at various level and it is enhanced by radioactivity content in soil and the transfer potentials through the environmental medium, food stuff and man linkages (Avwiri et al., 2013). The common types of naturally occurring radionuclides series formed in the food chain are ${ }^{238} \mathrm{U}$ and ${ }^{232} \mathrm{Th}$ and their progenies, while the non-series one is the ${ }^{40} \mathrm{~K}$ (the principal naturally occurring source of internal radiation), though it has a few isotopic abundances (ICRP, 2008, Avwiri et al., 2013).

In this work, the radionuclides and the activity concentration of ${ }^{238} \mathrm{U},{ }^{232} \mathrm{Th}$ and ${ }^{40} \mathrm{~K}$ were examined in some selected tubers (Yam (Discorea spp), Cassava (Manihot esculenta) and Sweet Potato (Ipomoea batatas)) in Ogbomoso area of Nigeria. It is important that the accessed food by the people is non-toxic and nutritionally sufficient (Jibiri et al., 2007, Avwiri et al 2011). Natural radioactive element continues to exist in the various environmental compartment by entering into the ecosystem and food chain (Avwiri et al., 2011).

\section{Materials and Methods}

Ogbomoso land which is approximately located between latitude $8^{0} 1^{\prime} 11^{\prime \prime} N$ and longitude $4^{0} 9^{\prime} 21^{\prime \prime} E$ of the Oyo North senatorial district of
Oyo state, Nigeria (Olafisoye et al., 2013). It is one of the largest cities in the southern Nigeria. It comprises of Ogbomoso North, Ogbomoso south, Surulere, Ogo-Oluwa and Orire local governments area. Fig. 1 shows the geologic formation of the area.

The study area was divided into four zones (ABCD) based on the soil formations and a total of twelve (12) samples of Yam (Discorea spp), Cassava (Manihot esculenta) and sweet potato (Ipomoea batatas) were collected directly from the farm lands that fell within each soil formation. Substantial quantity of the tuber samples that would be sufficient for analysis was collected. All these food samples were native to this study and represent the common food crops and choice of daily food needs and requirements of the population.

The tubers were sliced into pieces and washed firstly with bore hole water and then in distilled water shortly after collection from the study area. The samples (A, B, C, D) were then sun dried for a week to attain a constant weight after which they were crushed in wooden mortal with pestle, homogenized and sieved through a 1.00 $\mathrm{mm}$ mesh size. They were then transferred into uncontaminated uniform plastic containers which were tightly sealed for a period of 28 days (4 weeks). This was done in order to allow Radon and its progenies to assume secular equilibrium prior to gamma spectroscopy. The specimens were exposed to spectrometry system that consisted of a shielded and calibrated 3 inches by 3 inches $\mathrm{NaI}(\mathrm{TI})$ detector (a product of Gamma Tech., USA). This detector was coupled to GS -2000 - Gamma spectacular multi-channel analyzer for data analysis.An empty container was ab-initio counted for 10 hours to determine the background count. After attaining secular equilibrium, the samples were then introduced one after the other and counted for the same period as it was done with the empty container. The radionuclides characteristics for the measurement of the activity concentrations of the samples are $1460.0 \mathrm{keV}, 1764.5 \mathrm{keV}$ and $2614.7 \mathrm{keV}$ for ${ }^{40} \mathrm{~K},{ }^{238} \mathrm{U}$ and ${ }^{232} \mathrm{Th}$ respectively. 

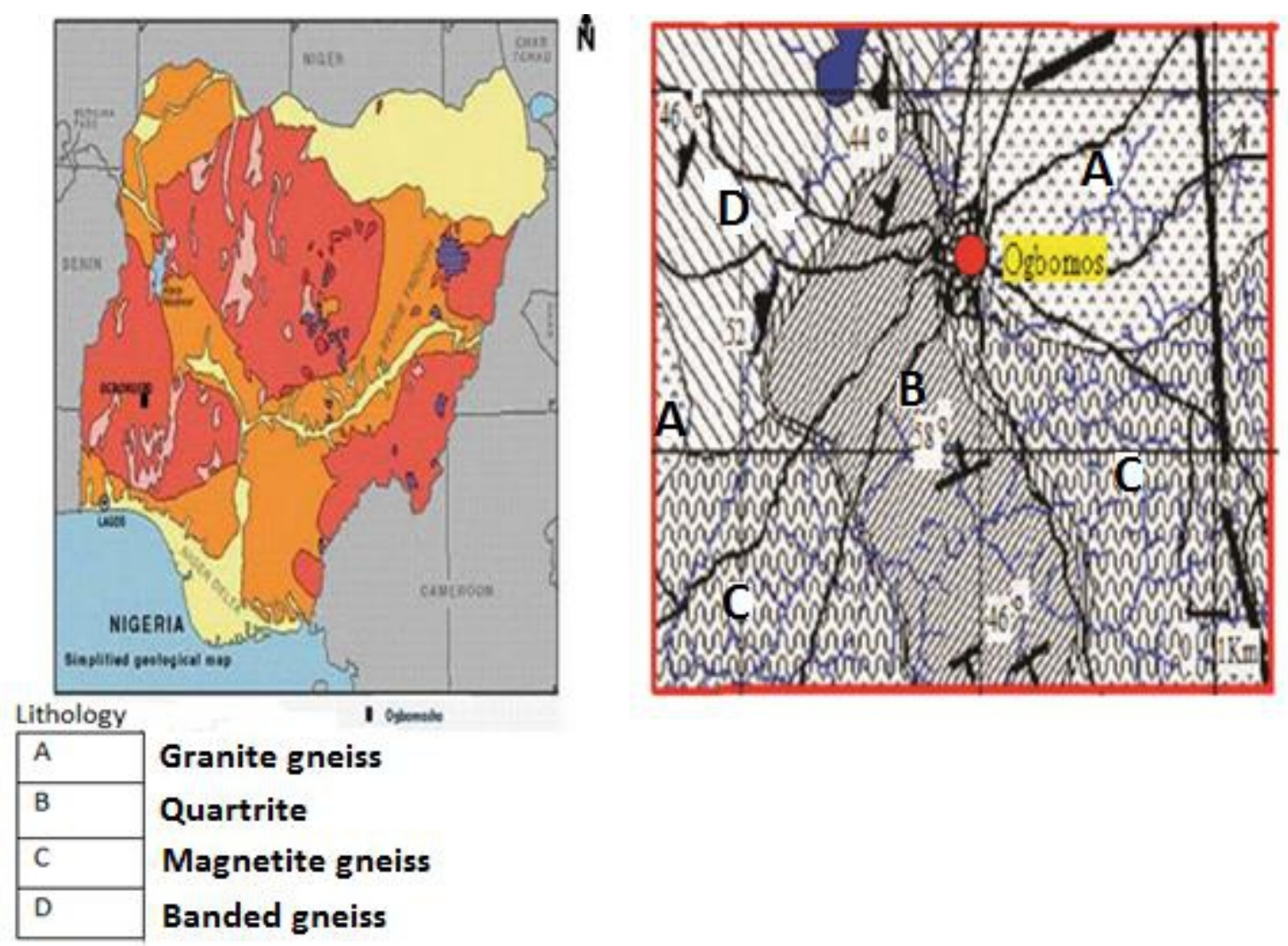

Fig. 1. Map of Nigeria and geologic map of Ogbomoso (Modified after Olafisoye et al., 2013)

\section{Result and Discussion}

Radioactivity Concentration in Cassava (Manihot esculenta)

The Specific Activity for ${ }^{40} \mathrm{~K}$ ranged from $748.74 \pm 41.68 \mathrm{BqKg}^{-1}$ in zone A to $1630.66 \pm 89.49 \mathrm{BqKg}^{-1}$ in zone $\mathrm{C}$ (Mean:1190.76 $\pm 77.10 \mathrm{BqKg}^{-1}{ }^{238} \mathrm{U}$ ranged from BDL (Below Detection Level (0) $\mathrm{BqKg} g^{-1}$ in zone B to $94.81 \pm 15.18 \mathrm{BqKg}^{-1}$ in zone $\mathrm{C}$ (Mean : $37.84 \pm 6.22 \mathrm{BqKg}^{-1}$ ) and ${ }^{232} \mathrm{Th}$ ranged from $3.49 \pm 0.24 \mathrm{BqKg}^{-1}$ in zone $\mathrm{B}$ to $28.72 \pm 1.85 \mathrm{BqKg}^{-1}$ in zone $\mathrm{C}$ (Mean : $\left.17.52 \pm 1.15 \mathrm{BqKg}^{-1}\right)$ as presented in Table 1a. Absorbed Dose Rate (ADR) (Beck and Planque, 1968, Beck et al, 1972), ranged from
$44.94 \mathrm{nGy} / \mathrm{h}$ in zone B to $115.03 \mathrm{nGy} / \mathrm{h}$ in zone C (Mean : $69.80 \mathrm{nGy} / \mathrm{h}$ ). The Radium equivalent $\left(R a_{e q}\right)$ (UNCEAR, 1982), ranged from $90.94 \mathrm{BqKg}^{-1}$ in zone $\mathrm{B}$ to $261.44 \mathrm{BqKg}^{-1}$ in zone $\mathrm{C}$ (Mean : $\left.154.59 \mathrm{BqKg}^{-1}\right)$ as presented in Table 1b. The External Hazard Index $\left(H_{e x}\right)$ (NEA, 1979, Shunga, 1988), ranged from 0.25 in zone B to 0.71 in zone $\mathrm{C}$ (Mean : 0.42 ) as presented in Table 1b. The Activity Concentration Index (ACI) (ECR, 1999), ranged from 0.38 in zone B to 1.00 in zone $C$ (Mean : 0.61 ) as presented in Table 1b. The Effective Dose Rate $\left(D_{E}\right)$, ranged from $31.46 \mathrm{mSv} / \mathrm{y}$ in zone B to $80.52 \mathrm{mSv} / \mathrm{yin}$ zone $\mathrm{C}$ (Mean $: 48.86 \mathrm{mSv} / \mathrm{y}$ ) as presented in Table $1 \mathrm{~b}$. 
Table 1a. Specific Gamma activity concentration for Cassava (Manihot esculenta) in Ogbomoso, South western, Nigeria.

\begin{tabular}{llll}
\hline & ${ }^{40} \mathbf{K}(\mathbf{B q} / \mathbf{k g})$ & ${ }^{238} \mathbf{U}(\mathbf{B q} / \mathbf{k g})$ & ${ }^{232} \mathbf{T h}(\mathbf{B q} / \mathbf{k g})$ \\
\hline A & $748 \pm 41.68$ & $54.07 \pm 9.15$ & $\mathbf{2 0 . 6 0} \pm \mathbf{6 7 . 4 9}$ \\
B & $1116.21 \pm 62.73$ & $B D L$ & $\mathbf{3 . 4 9} \pm \mathbf{0 . 2 4}$ \\
C & $1630.66 \pm 89.49$ & $94.81 \pm 15.18$ & $\mathbf{2 8 . 7 2} \pm \mathbf{1 . 8 5}$ \\
D & $1267.44 \pm 114.49$ & $2.49 \pm 0.54$ & $\mathbf{1 7 . 2 8} \pm \mathbf{1 . 1 5}$ \\
Mean & $1190.76 \pm 77.10$ & $37.84 \pm 6.22$ & $\mathbf{1 7 . 5 2} \pm \mathbf{1 . 1 5}$ \\
\hline
\end{tabular}

BDL means below detection level.

Table 1b. Absorbed Dose Rate (ADR), Radium equivalent activity $\left(R a_{e q}\right)$, External Hazard index $\left(H_{e x}\right)$, Activity Concentration Index (ACI) and effective dose $\operatorname{rate}\left(D_{E}\right)$ for Cassava (Manihot esculenta) in Ogbomoso Southwestern, Nigeria.

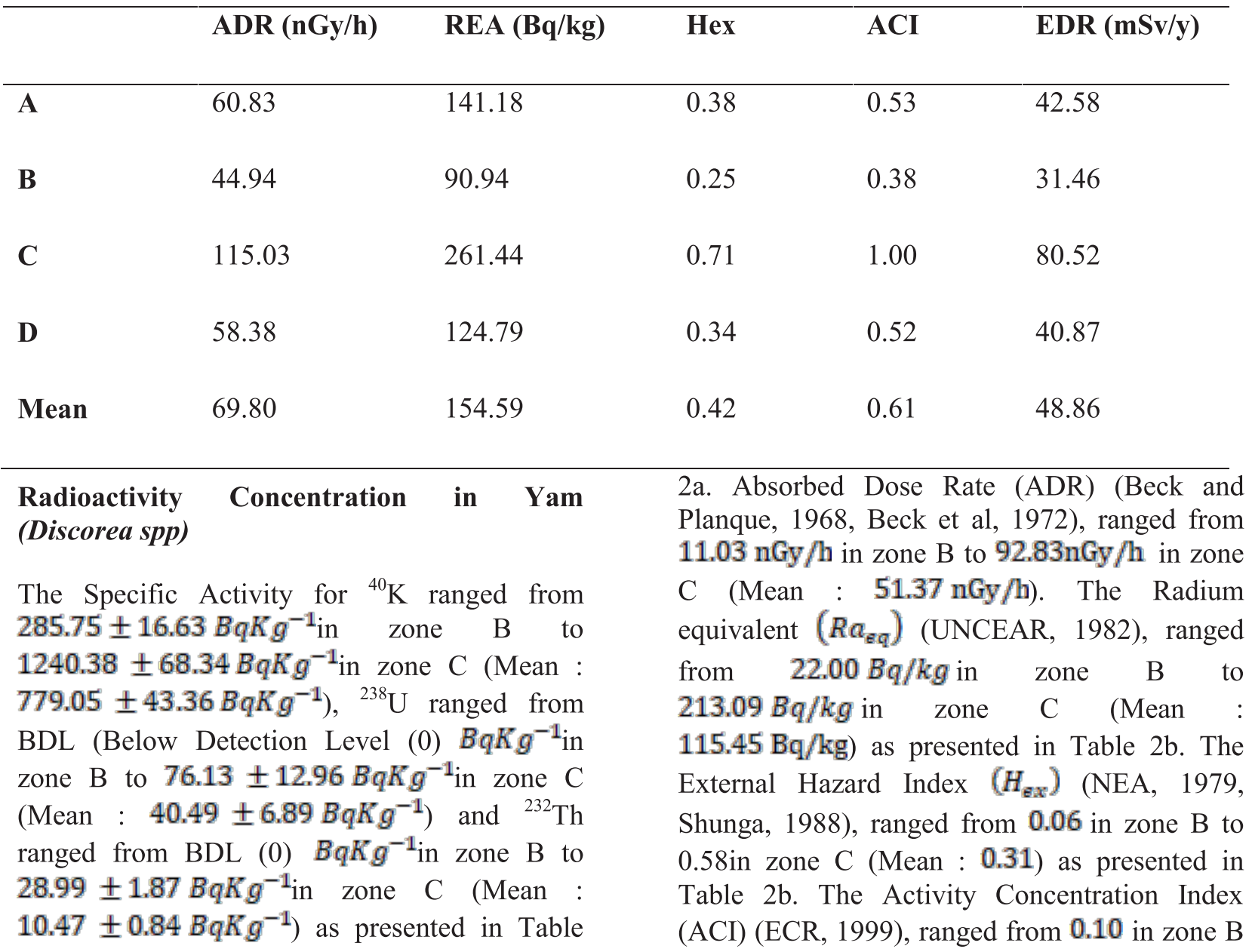


to 0.68 in zone $\mathrm{C}$ (Mean : 0.42 ) as presented in Table $2 \mathrm{~b}$. The Effective Dose Rate $\left(D_{E}\right)$, ranged from $7.72 \mathrm{mSv} / \mathrm{y}$ in zone B to $65.00 \mathrm{mSv} / \mathrm{y}$ in zone $\mathrm{C}($ Mean : $34.24 \mathrm{mSv} / \mathrm{y})$ as presented in Table $2 b$.

Table 2a. Gamma activity concentration for Yam (Discorea spp) in Ogbomoso, South western, Nigeria.

\begin{tabular}{llll}
\hline Site/location & ${ }^{40} \mathbf{K}(\mathbf{B q} / \mathbf{k g})$ & ${ }^{238} \mathbf{U}(\mathbf{B q} / \mathbf{k g})$ & \\
\hline $\mathbf{A}$ & $1227.11 \pm 67.49$ & $42.16 \pm 7.24$ & $9.97 \pm 1.29$ \\
$\mathbf{B}$ & $285.75 \pm 16.63$ & $B D L$ & $B D L$ \\
$\mathbf{C}$ & $1240.38 \pm 68.34$ & $76.13 \pm 2.96$ & $28.99 \pm 1.87$ \\
D & $362.96 \pm 20.98$ & $43.67 \pm 7.35$ & $2.91 \pm 0.19$ \\
Mean & $779.05 \pm 43.36$ & $40.49 \pm 6.89$ & $10.47 \pm 0.84$ \\
\hline
\end{tabular}

BDL means below detection level.

Table 2b. Absorbed Dose Rate (ADR), Radium equivalent activity $\left(R a_{e q}\right)$, External Hazard index $\left(H_{e x}\right)$, Activity Concentration Index $(A C I)$ and effective dose rate $\left(D_{E}\right)$ for Yam (Discorea spp) in Ogbomoso Southwestern, Nigeria.

\begin{tabular}{llllll}
\hline Site/location & ADR $(\mathbf{n G y} / \mathbf{h})$ & REA $(\mathbf{B q} / \mathbf{k g})$ & Hex & ACI & EDR (mSv/y) \\
\hline A & 69.05 & 150.90 & 0.41 & 0.60 & 41.43 \\
B & 11.03 & 22.00 & 0.06 & 0.10 & 7.72 \\
C & 92.83 & 213.09 & 0.58 & 0.68 & 65.00 \\
D & 32.55 & 75.77 & 0.20 & 0.28 & 22.79 \\
Mean & 51.37 & 115.45 & 0.31 & 0.42 & 34.24 \\
\hline
\end{tabular}

\section{Radioactivity Concentration in Potato (Ipomoea batatas)}

The Specific Activity for ${ }^{40} \mathrm{~K}$ ranged from $568.58 \pm 32.25 \mathrm{BqKg}^{-1}$ in zone $\mathrm{B}$ to $1674.71 \pm 92.33 \mathrm{BqKg}^{-1}$ in zone A (Mean : $\left.1282.83 \pm 71.33 \mathrm{BqKg}^{-1}\right),{ }^{238} \mathrm{U}$ ranged from BDL (Below Detection Level (0) $B q K^{-1}$ in zone $\mathrm{B}$ to $59.23 \pm 10.15 \mathrm{BqKg}^{-1}$ in zone $\mathrm{D}$ (Mean : $37.80 \pm 6.51 \mathrm{BqKg}^{-1}$ ) and ${ }^{232} \mathrm{Th}$ ranged from $16.18 \pm 1.07 \mathrm{BqKg}^{-1}$ in zone $\mathrm{B}$ to $27.91 \pm 1.79 \mathrm{BqKg}^{-1}$ in zone A (Mean : $\left.21.13 \pm 1.37 \mathrm{BqKg}^{-1}\right)$ as presented in Table 2a. Absorbed Dose Rate (ADR) (Beck and Planque, 1968, Beck et al, 1972), ranged from $30.50 \mathrm{nGy} / \mathrm{h}$ in zone B to $93.93 \mathrm{nGy} / \mathrm{h}$ in zone C (Mean : $75.39 \mathrm{nGy} / \mathrm{h}$ ). The Radium equivalent $\left(R a_{\text {eq }}\right)$ (UNCEAR, 1982), ranged from $22.00 \mathrm{BqKg}^{-1}$ in zone $\mathrm{B}$ to $213.09 \mathrm{BqKg}^{-1}$ in zone C (Mean : 
$115.45 \mathrm{~Bq} / \mathrm{kg}$ ) as presented in Table $2 \mathrm{~b}$. The External Hazard Index $\left(H_{e x}\right)$ (NEA, 1979, Shunga, 1988), ranged from 0.06 in zone B to 0.58in zone $\mathrm{C}$ (Mean : 0.31) as presented in Table 2b. The Activity Concentration Index (ACI) (ECR, 1999), ranged from 0.10 in zone B to 0.68 in zone $\mathrm{C}$ (Mean : 0.42 ) as presented in Table $2 \mathrm{~b}$. The Effective Dose Rate $\left(D_{E}\right)$, ranged from $7.72 \mathrm{mSv} / \mathrm{y}$ in zone B to $65.00 \mathrm{mSv} / \mathrm{y}$ in zone $\mathrm{C}$ (Mean : $34.24 \mathrm{mSv} / \mathrm{y}$ ) as presented in Table 2b.

Table 3a. Gamma activity concentration for Potato (Ipomoea batatas)

\begin{tabular}{llll}
\hline Site/location & ${ }^{40} \mathbf{K}(\mathbf{B q} / \mathbf{k g})$ & ${ }^{238} \mathbf{U}(\mathbf{B q} / \mathbf{k g})$ & ${ }^{232} \mathbf{T h}(\mathbf{B q} / \mathbf{k g})$ \\
\hline $\mathbf{A}$ & $1674.71 \pm 92.33$ & $33.71 \pm 5.81$ & $27.91 \pm 1.79$ \\
B & $568.58 \pm 32.25$ & $B D L$ & $16.18 \pm 1.07$ \\
C & $1521.62 \pm 84.38$ & $58.25 \pm 10.06$ & $23.68 \pm 1.53$ \\
D & $1366.40 \pm 76.34$ & $59.23 \pm 10.15$ & $16.68 \pm 1.09$ \\
Mean & $1282.83 \pm 71.33$ & $37.80 \pm 6.51$ & $21.13 \pm 1.37$ \\
\hline
\end{tabular}

BDL means below detection level.

Table 3b. Absorbed Dose Rate (ADR), Radium equivalent activity $\left(R a_{e q}\right)$, External Hazard index $\left(H_{e x}\right)$, Activity Concentration Index (ACI) and effective dose rate $\left(D_{E}\right)$ for Potato (Ipomoea batatas) in Ogbomoso Southwestern, Nigeria.

\begin{tabular}{lccccc}
\hline & ADR (nGy/h) & REA (Bq/kg) & Hex & ACI & EDR (mSv/y) \\
\hline A & 92.52 & 202.57 & 0.55 & 0.81 & 64.76 \\
B & 30.50 & 66.92 & 0.18 & 0.27 & 21.35 \\
C & 93.93 & 209.28 & 0.57 & 0.82 & 65.75 \\
D & 84.62 & 188.30 & 0.51 & 0.74 & 59.23 \\
Mean & 75.39 & 166.77 & 0.45 & 0.66 & 52.77 \\
\hline
\end{tabular}




\section{Conclusion.}

The results showed that all tubers majorly absorbed ${ }^{40} \mathrm{~K}$ more than ${ }^{238} \mathrm{U}$ and ${ }^{232} \mathrm{Th}$. This is due to the fact that potassium is an essential element and tubers do not have the ability of differentiating each element, thus ${ }^{40} \mathrm{~K}$ is preferred above the two other radionuclides. Cassava from Surulere local government (C) absorbed the highest amount of ${ }^{40} \mathrm{~K}$ concentration of $1630 \pm 89.49 \mathrm{~Bq} / \mathrm{kg}$ through root and leaves uptake as a result of atmospheric

\section{References}

Ademola, J. A (2008). Assessment of natural radioactivity contents of cements used in Nigeria. Journal of Radiol. Protection. 28:581588

Arogunjo, A. M. (2004). Terrestrial Gamma Radiation and the Radiological implication in South Western Nigeria. Journal of applied sciences, 7: 1534-1537.

Avwiri, G. O \&Osarulube, G. O. (2011). Assessment of Norm-containing food crop/stuffs in OML 58 \& OML 61 within the Niger Delta region of Nigeria. Greener Journals. Research paper.

Avwiri, G.O., Osimobi, J.C. \&Agbalagba, E.O. (2013). Evaluation of Natural occurring radionuclide variation with lithology depth profile of Udi and Ezeagu Local Government areas of Enugu State, Nigeria. International Journal of Engineering and Applied Sciences 4(3) p1-10

Balakrishna, R., Antoniou, C., Ben-Akiva, M., Koutsopulos, H. N. \& Wen, Y. (2007). Calibration of microscopic traffic simulation models: methods and application. Transportation Research Record, p198-207

Beck, H. L., Planque, G., (1968). The radiation field in air due to distributed gamma ray sources in ground. HASL-195, Environmental Measurements Laboratory, New York: U.S. DOE.
deposit.The activity concentration of the natural radionuclides in the food crops ranged from $(285.75 \pm 16.63$ and $1674.71 \pm 92.33) \mathrm{Bq} / \mathrm{kg}$ for ${ }^{40} \mathrm{~K},(2.49 \pm 0.54$ and $15.18 \pm 1.34) \mathrm{Bq} / \mathrm{kg}$ for ${ }^{238} \mathrm{U},(2.91 \pm 0.19$ and $28.99 \pm 1.87) \mathrm{Bq} / \mathrm{kg}$ for ${ }^{232} \mathrm{Th}$. However, the results of the study indicate that the dose taken from ${ }^{238} \mathrm{U}$ and ${ }^{232} \mathrm{Th}$ intake are low and are not harmful, while that of ${ }^{40} \mathrm{~K}$ is a little bit higher against the recommended limit of $100 \mathrm{~Bq} / \mathrm{kg}$ (WHO, 2012), this can cause high level of potassium in the blood (Ozanne, 2015).

Beck, H. L., DeCampo, J., Gogolak, C., (1972). In-situ $\mathrm{Ge}(\mathrm{Li})$ and $\mathrm{NaI}(\mathrm{Tl})$ gamma-ray spectrometry HASL-258, Environmental Measurements Laboratory, New York: U.S. DOE.

Beretka, J. \& Mathew, P. J. (1985). Natural radioactivity in Australian building materials, industrial waste and by-product. Health Phys. $\mathrm{p} 48,87-95$.

Hayumbu, P., Zaman, M. B., Lubaba, N.C. H., Munsanje, S. S. \&Nuleya, D. (1995). Natural radioactivity in Zambian building materials collected from Lusaka. J. Radioanal. Nucl. Chem. p199, 229-238.

Jwambot, D. I., Izam, M. M., \&Nyam, G.G. (2012). Radioactivity in some food crops from High background Radiation area on the JosPlateau, Nigeria. Journal of Natural Science Research. 2(6) p76-79.

International Commission on Radiological Protection (2008). Environmental Protection the concept and use of reference animals and plants. Elsevier. P 4-6.

Jibiri, N.N., Farai, I. P. \&Alausa, S. K. (2007). Estimation of annual effective dose due to natural radioactive elements in ingestion of food stuff in mining area of Jos-Plateau, Nigeria. Journal of Environmental Radioactivity 94(1): $31-40$. 
Nuclear Energy Agency (1979). Exposure to radiation from natural radioactivity in building materials. Report by NEA Group of Experts, OECD: Paris, France.

Olafisoye, E. R, Sunmonu, L. A., Adagunodo, T. A. \&Oladejo, O. P. (2013). Impact assessment of solid waste on Groundwater: A case study of Aarada Dumpsite, Ogbomoso, Nigeria. ARPN Journal of Earth Sciences.

Ozanne S. E. (2015). Epigenetics and Metabolism in Metabolic Programming: Known, Unknown and Possibilities. Nat Rev Endocrinol 11:67-68.

Saleh, I. H. (2011). Radioactivity of ${ }^{238} \mathrm{U},{ }^{232} \mathrm{TH}$, ${ }^{40} \mathrm{~K}$ and ${ }^{137} \mathrm{CS}$ and assessment of deplected
Uranium in soil of the Musandan peninsula, Sultanate of Oman. Turkish Journal of Engineering and Environmental sciences, 36(2011), pp 236-248.

Slunga, E. Radon (1988). Classification of building ground. Radiation Protection Dosimetryp24 (114), 39-42.

UNSCEAR (1982). Ionizing Radiation sources and biological effects. A/37/45, United Nations, New York.

WHO (2012). New standard limits for Radionuclides in food. Ministry of Health, Labour and Welfare. New York 